\title{
Effect of educational intervention based on locus of control structure of attribution theory on self-care behavior of patients with type II diabetes
}

\author{
Farbod Ebadi Fardazar ${ }^{1}$, Hassan Heidari², Mahnaz Solhi ${ }^{1 *}$ \\ Received: 15 Feb 2016 \\ Published: 21 Dec 2017
}

\begin{abstract}
Background: Different factors, such as personality and psychological characteristics, are effective in the self-care and control of diabetes. This study aimed at determining the effect of educational intervention based on locus of control structure of attribution theory on the self-care behavior of patients with type II diabetes.

Methods: This was a quasi-experimental controlled study performed on 180 patients in Babol Diabetes Association. The sampling method was simple random sampling. Data collection tool was form $\mathrm{C}$ of standard questionnaire in multidimensional health locus of control (MHLC) and summary of diabetes self-care activities (SDSCA). Based on the results obtained from the initial completion of the questionnaires, educational intervention was designed as three 60-minute educational sessions using short lectures, question and answer, group discussions, and consultation methods, as well as educational materials, such as films, posters, and pamphlets. Intervention was only performed for the test group. The questionnaires were filled out again 2 and 3 months after the intervention.

Results: Before the intervention, there was no significant difference in the mean scores of self-care, internal, chance, and external locus of control between the 2 groups. However, 2 to 3 months after the intervention, the mean scores of self-care (p<0.001) and locus of control $(p<0.001)$ increased in the test group. Moreover, the mean score of chance $(p<0.001)$ and external $(p<0.001)$ locus of control decreased significantly.

Conclusion: Educational intervention decreases the mean scores of chance and external locus of control and increases the mean score of internal locus of control; as a result, it improves self-care in patients with diabetes.
\end{abstract}

Keywords: Educational intervention, Self-care, Health locus of control, Type II diabetes

Copyright $@$ Iran University of Medical Sciences

Cite this article as: Ebadi Fardazar F, Heidari H, Solhi M. Effect of educational intervention based on locus of control structure of attribution theory on self-care behavior of patients with type II diabetes. Med J Islam Repub Iran. 2017 (21 Dec);31:116. https://doi.org/10.14196/mjiri.31.116

\section{Introduction}

Diabetes has increasingly received more attention due to its dangerous complications. Diabetes has involved millions of people worldwide (1). Diabetes, especially Type 2 , has become one of the main threats to human health in the 21 st century. This disease has become one of the global health problems and the main cause of death and disability; its vascular complications during lifetime lead to the huge increase of heart attacks and strokes, kidney failure, blindness, and amputation (2). Many studies have demonstrated that patients with diabetes, despite having relatively normal life for a long time, suffer from diabetic

Corresponding author:DrMahnaz Solhi, solhi.m@iums.ac.ir

1. Health Promotion Research Center, Iran University of Medical Sciences, Tehran, Iran.

2. Department of Health Services and Health Education, School of Health, Iran University of Medical Sciences, Tehran, Iran. complications, such as neuropathy, nephropathy, and heart attack (3). Mortality rate of people with diabetes is 2 to 3 times higher than that of healthy individuals (4). Every year, more than 7 million people around the world suffer from diabetes and more than 3.8 million deaths occur due to diabetes, ie, 1 death occurs in patients with diabetes every 10 seconds. According to previous studies, the number of patients with diabetes in Iran was equal to 2 872000 in 2010 , which is predicted to be increased to 5 981000 people in 2030 , ie, 155000 patients with diabetes per year (5). In 2008, Yazdan Panah et al. reported the

$\uparrow$ What is "already known" in this topic:

Identifying diabetic patients with internal, external and chance attribution styles can be effective in identifying their behaviors to better control the disease.

$\rightarrow$ What this article adds:

Education based on locus of control structure of attribution theory has a positive effect on self-care in patients with diabetes through decreasing external and chance locus of control and increasing internal locus of control. 
prevalence of diabetes to be $17 \%$ among the population aged 30 to 65 years in the west of Yasouj (6). Due to the growing trend of diabetes in the world, World Health Organization has considered it a hidden epidemic, and has called all the countries to cope with this epidemic since 2014 (7). One of the reasons for the lack of success and achievement of favorable treatment outcomes in patients with diabetes is the low participation of patients in treatment because they and their families need to learn and practice new lifestyle skills, such as monitoring blood glucose, selecting proper diet, and being more active. These skills are important for preventing and controlling diabetes, and delaying its complications (8). The increased knowledge of patients about diabetes' different problems including principles of self-care, continuous blood glucose control, and maintain it at the normal level could prevent early and late complications, ensure long lifetime for patients, and decrease treatment costs. Undoubtedly, achieving these objectives requires public participation, as well as dynamic and continuous education; without educating the patients and their participation in the self-care process, performing health care will be costly and quality of life of patients will decrease (9). Self-care, which is a strategy to comply with events and stresses of life and can improve health and independence, includes special activities to reduce the symptoms (10). Knowledge and type of attitude towards the disease, which could help control it, is highly important for patients with diabetes (11). Some studies have been performed on self-care education (12-14). In some of these studies, the role of educational interventions in diabetes has been evaluated, and it has been found that the interventions with the aim of behavioral changes are effective in improving self-care abilities, controlling diabetes, and enhancing quality of life of patients with diabetes (15). Results of a study indicated that health education improves quality of life of patients with diabetes and increases the mean scores of quality of life by $18.4 \pm 0.6(16)$. Numerous studies in different parts of the world have also indicated that educating patients with diabetes could improve the hemoglobin profile (HbA1C) in fasting glucose and the metabolic status of diabetic patients (17-19). Tendency of people to attribute the behavior to external causes and factors is called attribution style (20). According to the studies on attribution styles, people attribute their diseases to personal or environmental factors; hence, there are 2 locuses of control, internal and external, in the attribution theory (21). Those who search the reasons for the behaviors in themselves would refine and modify their behaviors, without expecting help from others, waiting for others to help, relying on others' encouragement to take a step, and justifying their behaviors instead of self-analysis and judging themselves. Therefore, they would achieve success and can fulfill most of their dreams. In contrast, those who often attribute the reasons for their behaviors to something outside themselves, would blame others for their failure, wait for others to help, and usually do not correct their viewpoints (22). Hence, identifying diabetic patients with internal, external, and chance attribution styles can help identify their behaviors to better control the disease. Therefore, considering the importance of lo- cus of control and self-care education in patients with diabetes, this study aimed at evaluating the effect of educational intervention based on locus of control structure of attribution theory on the self-care behavior of patients with type II diabetes in Babol Diabetes Association. The results can be applied to design improvement programs for patients based on locus of control structure in health centers, health houses, hospitals, diabetes centers, as well as diabetes associations, and other organizations.

\section{Methods}

This was a semi-experimental controlled research performed on 180 patients in Babol Diabetes Association. This study aimed at determining the effect of educational intervention based on locus of control structure of attribution theory on self-care behavior. The sampling method was simple random sampling. First, among 7200 members of Babol Diabetes Association, using the formula for comparing the means of the 2 independent groups, a total of 82 participants was determined as the sample size. Considering almost $10 \%$ extra sample size for the loss in the second step, the total number of samples was estimated to be 90 in each group. Then, the participants were randomly divided into 2 groups of test and control. The inclusion criteria were membership in Babol Diabetes Association and having type II diabetes. Based on Social research ethics protocol, the participants in the 2 groups should not have had any relationship with each other.

One of the data collection tools was a C-form standard questionnaire in multidimensional health locus of control (MHLC), with a 6-point Likert scale. In this form, 6 items measured beliefs of people in the internal control of health, and 12 remaining items measured the effect of factors such as chance, powerful others, doctors, and people on personal health, representing external locus of control for health. Scores 1 to 6 were considered for the options from strongly agree to strongly disagree; therefore, the score could vary from 6 to 36 for each subtest, which is not summed and estimated independently. Multidimensional health locus of control (MHLC) questionnaire was designed by Walston and Devlis; and its validity and reliability have been formerly estimated by Kohara et al. (23) as 0.62 and 0.76 , by Nikogoftar (24) as 0.70 , by Moshki et al. (25) as $0.70,0.75$, and 0.69 for each of the components of internal, external, and chance locus of control, and by Hatamloye Sadabadi et al. (26) as 0.94, 0.65, and 0.90 for each of the components of internal locus of control, external locus of control, powerful others, and chance, respectively.

Another data collection tool was summary of diabetes self-care activities (SDSCA), which includes 11 questions to measure 5 aspects: diet, physical activity, blood glucose testing, foot care, and smoking. The respondents reported the frequency of performed activities during 7 previous days on a 0 to 7 scale. In total, the mean scores of 11 items showed the self-care level of the person in doing the assignments related to diabetes. Except in Question 4, the higher the score of the questions, the higher the total score, ie, self-care is done in a better way. Question 11 is a yes/no question, in which a no response indicates better 
self-care. This questionnaire has been evaluated by Skinner and Hamsun, and its internal consistency coefficient was obtained as 0.82 in the English edition by the producer, 0.85 in the Spanish edition (27), and 0.65 in the Persian edition by Nikogoftar, as well as 0.82 by Hatamloye Sadabadi et al. $(24,26,27)$.

In the pretest step, the questionnaires were completed by all participants in the 2 groups. According to the analysis of the pretest results, the self-care educational course in diabetes was designed and was then performed and modified according to the experts' opinions. The educational intervention included 3 educational sessions based on locus of control structure of attribution theory (internal, external, and chance) and self-care in diabetes. Each session contained a 60- minute education by short lectures, question and answer, group discussions, and consultation methods using educational materials, such as films, posters, and pamphlets. Then, the designed educational intervention was only performed for the test group. The questionnaires were completed again in both groups 2 to 3 months after the intervention in the posttest. The data obtained in SPSS20 software were analyzed using descriptive (number, percentage, mean, and standard deviation) and analytical (Pearson's correlation coefficient, regression analysis, paired t test, and chi square) tests.

Ethical considerations were observed based on the social research ethics protocol and informed consent was obtained from participants in the study.

\section{Results}

Minimum age in the test and control groups was 35 and 36 years, respectively, and maximum age was 80 years in both groups. Mean \pm SD age in the test and control groups was $57.33 \pm 9.6$ and $58.74 \pm 9.5$ years, respectively. Independent $\mathrm{t}$ test did not reveal a significant difference between the 2 groups in age $(p=0.325)$. The result of chi square test (root mean square) showed no significant difference between the control and test groups in sex, education, and employment (Table 1).

A significant difference was found between the mean scores of self-care, internal, external, and chance locus of control before and 2 months after the intervention $(\mathrm{p}<0.001)$ (Table 2). However, no significant difference was observed between the 2 groups in the mean score of internal locus of control before educational intervention. However, as it has been demonstrated in Table 2, internal locus of control mean score increased in the test group 2 months after the intervention, and a significant difference was observed $(\mathrm{p}<0.001)$.

Self-care mean score increased after the educational intervention in the test group, indicating a statistically significant difference $(p<0.001)$. The control group also demonstrated a significant difference in the opposite direction so that the mean score of self-care decreased in the control group by 0.78 two months after the educational intervention and became significant in the opposite direction (Table 2). It decreased in the control group by 1.10 during the 3 months after the educational intervention and became significant in the opposite direction (Table 3).

Table 1. Demographic variables of the participants

\begin{tabular}{|c|c|c|c|c|c|c|}
\hline \multirow[t]{2}{*}{ Studied variable } & \multirow[t]{2}{*}{ Category } & \multicolumn{2}{|c|}{ Test } & \multicolumn{2}{|c|}{ Control } & \multirow{2}{*}{$\begin{array}{c}\chi^{2} \text { test } \\
\text { P-value }\end{array}$} \\
\hline & & Number & Percentage & Number & Percentage & \\
\hline \multirow[t]{2}{*}{ Sex } & Male & 39 & 43.3 & 36 & 40.0 & \multirow[t]{2}{*}{$\mathrm{p}=0.650$} \\
\hline & Female & 51 & 56.7 & 54 & 60.0 & \\
\hline \multirow{3}{*}{ Education } & Illiterate & 29 & 32.2 & 24 & 26.7 & \multirow{3}{*}{$\mathrm{p}=0.482$} \\
\hline & Elementary to high school diploma & 47 & 52.2 & 55 & 61.1 & \\
\hline & Academic & 14 & 15.6 & 11 & 12.2 & \\
\hline \multirow[t]{3}{*}{ Employment } & Housewife & 40 & 44.4 & 35 & 38.9 & \multirow{3}{*}{$\mathrm{p}=0.379$} \\
\hline & Retired & 18 & 20.0 & 14 & 15.6 & \\
\hline & Employed & 32 & 35.6 & 41 & 45.6 & \\
\hline
\end{tabular}

Table 2. Comparing the mean and standard deviation of the studied variables before and 2 months after the educational intervention in the test and control groups

\begin{tabular}{|c|c|c|c|c|c|c|c|c|c|}
\hline \multirow{3}{*}{$\begin{array}{l}\text { Studied } \\
\text { variables }\end{array}$} & \multirow[t]{2}{*}{ Intervention time } & \multicolumn{2}{|c|}{ Test } & \multirow{2}{*}{$\begin{array}{c}\text { Mean } \\
\text { differences }\end{array}$} & \multirow{2}{*}{$\begin{array}{c}\text { Paired } \mathrm{t} . \\
\text { test } \\
\mathrm{P}_{\text {value }}\end{array}$} & \multicolumn{2}{|c|}{ Control } & \multirow{2}{*}{$\begin{array}{c}\text { Mean } \\
\text { differences }\end{array}$} & \multirow{2}{*}{$\begin{array}{c}\text { Paired } \mathrm{t} \\
\text { test } \\
\mathrm{P}_{\text {value }}\end{array}$} \\
\hline & & Mean & $\begin{array}{l}\text { Standard } \\
\text { deviation }\end{array}$ & & & Mean & $\begin{array}{l}\text { Standard } \\
\text { deviation }\end{array}$ & & \\
\hline & $\begin{array}{l}\text { Before educational } \\
\text { intervention }\end{array}$ & 24.98 & 13.3 & 4.03 & 0.001 & 21.12 & 10.4 & -0.78 & 0.001 \\
\hline Self-care & $\begin{array}{l}2 \text { months after } \\
\text { educational inter- } \\
\text { vention }\end{array}$ & 29.01 & 13.1 & & & 20.34 & 10.5 & & \\
\hline Internal & $\begin{array}{l}\text { Before educational } \\
\text { intervention }\end{array}$ & 21.56 & 5.3 & 3.97 & 0.001 & 21.95 & 4.2 & -0.15 & 0.109 \\
\hline $\begin{array}{l}\text { locus of } \\
\text { control }\end{array}$ & $\begin{array}{l}2 \text { months after } \\
\text { educational inter- } \\
\text { vention }\end{array}$ & 25.53 & 5.5 & & & 21.80 & 4.2 & & \\
\hline Chance & $\begin{array}{l}\text { Before educational } \\
\text { intervention }\end{array}$ & 25.02 & 7.1 & -2.27 & 0.001 & 27.34 & 6.8 & 0.02 & 0.765 \\
\hline $\begin{array}{l}\text { locus of } \\
\text { control }\end{array}$ & $\begin{array}{l}2 \text { months after } \\
\text { educational inter- } \\
\text { vention }\end{array}$ & 22.75 & 7.0 & & & 27.36 & 6.7 & & \\
\hline $\begin{array}{l}\text { External } \\
\text { locus of } \\
\text { control }\end{array}$ & $\begin{array}{l}\text { Before educational } \\
\text { intervention }\end{array}$ & 26.88 & 4.2 & -2.56 & 0.001 & 27.44 & 3.9 & -0.15 & 0.207 \\
\hline
\end{tabular}


Table 3. Comparing the mean and standard deviation of the studied variables before and 3 months after the educational intervention in the test and control groups

\begin{tabular}{|c|c|c|c|c|c|c|c|c|c|}
\hline \multirow{2}{*}{$\begin{array}{l}\text { Studied } \\
\text { variables }\end{array}$} & \multirow[t]{2}{*}{ Intervention time } & \multicolumn{2}{|c|}{ Test } & \multirow{2}{*}{$\begin{array}{l}\text { Mean } \\
\text { differ- } \\
\text { ences }\end{array}$} & \multirow{2}{*}{$\begin{array}{c}\text { Paired t. test } \\
\mathrm{P}_{\text {value }}\end{array}$} & \multicolumn{2}{|c|}{ Control } & \multirow{2}{*}{$\begin{array}{c}\text { Mean } \\
\text { differences }\end{array}$} & \multirow{2}{*}{$\begin{array}{l}\text { Paired t. test } \\
\mathrm{P}_{\text {value }}\end{array}$} \\
\hline & & Mean & $\begin{array}{l}\text { Standard } \\
\text { deviation }\end{array}$ & & & Mean & $\begin{array}{l}\text { Standard } \\
\text { deviation }\end{array}$ & & \\
\hline & $\begin{array}{l}\text { Before educational } \\
\text { intervention }\end{array}$ & 24.98 & 13.3 & 3.84 & 0.001 & 21.12 & 10.4 & -1.10 & 0.001 \\
\hline Self-care & $\begin{array}{l}3 \text { months after } \\
\text { educational inter- } \\
\text { vention }\end{array}$ & 28.82 & 13.0 & & & 20.02 & 10.5 & & \\
\hline Internal & $\begin{array}{l}\text { Before educational } \\
\text { intervention }\end{array}$ & 21.56 & 5.3 & 3.94 & 0.001 & 21.95 & 4.2 & -0.19 & 0.147 \\
\hline $\begin{array}{l}\text { locus of } \\
\text { control }\end{array}$ & $\begin{array}{l}3 \text { months after } \\
\text { educational inter- } \\
\text { vention }\end{array}$ & 25.50 & 5.3 & & & 21.76 & 4.3 & & \\
\hline Chance locus & $\begin{array}{l}\text { Before educational } \\
\text { intervention }\end{array}$ & 25.02 & 7.1 & -2.29 & 0.001 & 27.34 & 6.8 & 0.12 & 0.403 \\
\hline of control & $\begin{array}{l}3 \text { months after } \\
\text { educational inter- } \\
\text { vention }\end{array}$ & 22.73 & 6.8 & & & 27.46 & 6.5 & & \\
\hline External & $\begin{array}{l}\text { Before educational } \\
\text { intervention }\end{array}$ & 26.88 & 4.2 & -2.54 & 0.001 & 27.44 & 3.9 & -0.18 & 0.238 \\
\hline $\begin{array}{l}\text { locus of } \\
\text { control }\end{array}$ & $\begin{array}{c}3 \text { months after } \\
\text { educational inter- } \\
\text { vention }\end{array}$ & 24.34 & 4.3 & & & 27.26 & 3.7 & & \\
\hline
\end{tabular}

The result of paired test indicated that the mean scores of chance and external locus of control in the test group decreased after the intervention, and the difference was statistically significant $(\mathrm{p}<0.001)$. However, no significant difference was observed in the control group.

Comparison before and 3 months after the intervention was also repeated, similar to the 2 months after the intervention, and it was found that the mean differences in the self-care and internal locus of control increased in the test group, showing a statistically significant difference $(p<0.001)$. Nonetheless, no significant difference was observed in the internal locus of control in the control group, and self-care became significant in the negative direction (Table 3). Regarding the external and chance locus of control before and 3 months after the intervention, like the previous step, the mean differences decreased and became statistically significant $(\mathrm{p}<0.001)$, while no significant difference was observed in the control group (Table 3 ).

RMA (repeated measure ANOVA) analysis also revealed a significant difference among the mean scores of self-care, internal, external, and chance locus of control before and 2 to 3 months after the intervention (Diagram $1)$.

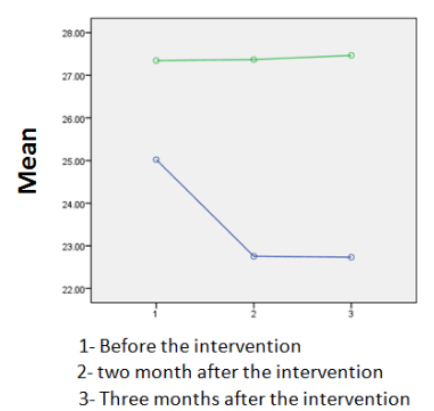

chance locus of control

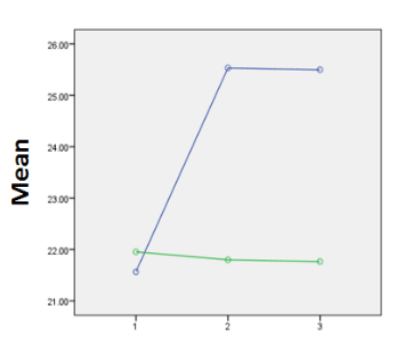

1- Before the intervention

2- two month after the intervention

3- Three months after the intervention

Internal locus of control


1- Before the intervention

2- two month after the intervention

3- Three months after the intervention

Self- care


1- Before the intervention

2-two month after the intervention

3-Three months after the intervention

External locus of control
Group
- case
control

Group

- case

Diagram 1. Comparing the mean scores of self-care, internal, external, and chance locus of control before and to 3 months after the intervention 


\section{Discussion}

In diabetes, different psychological factors, such as health locus of control, are important, which could create sense of responsibility in controlling the disease and selfcare. In this study, the mean score of self-care increased significantly 2 to 3 months after the educational intervention in the test group. Solhi et al. confirmed the effect of educational program on self-care in patients with type II diabetes (28). Many studies have shown the increased level of self-care because of educational intervention (29 to 34). According to Jacobson et al., the necessity for diabetes control is the self-management of patients, which is a lifelong attempt to maintain quality of life (35). Therefore, the designed intervention is effective for self-care improvement.

In the present study, the mean score of internal locus of control in the test group significantly increased 2 to 3 months after the intervention. The health locus of control is the belief of the person that his/her health is controlled by the external or internal factors. Those with the internal health locus of control have a greater control over their blood glucose levels, ie, those who believe that the main reason of their health is in themselves pay more attention to the treatment regimens and are less involved in the complications of the disease. Thus, the internal health locus of control increases the person's ability in self-care behaviors and induces better control over diabetes. Also, those who believe their health is related to their personal behavior are more responsible for their health than those with a higher tendency towards the external locus of control. Brown and Fist showed that the individuals with internal control had better quality of life and health than the control group (36). Results of other studies have demonstrated that educational interventions increase self-efficacy (37), self-management (38-39), and health assessment (40). Therefore, the designed intervention is effective to increase the internal locus of control score. In this study, the mean score of the internal and chance locus of control in the test group significantly decreased 2 to 3 months after the educational intervention. Moaieni et al. indicated that educational intervention in the regular physical activity in the intervention group increased significantly compared with the control group $(p<0.05)(41)$. Agha Molaie et al. found that educational intervention significantly $(p<0.05)$ changed the behavior of the patients with diabetes (29). Hazavehi et al. demonstrated the effect of the educational program in caring for diabetic foot, and they found a significant difference in before and after the educational intervention in the test group (32). Baghiani Moghdam et al. showed the effect of the educational intervention on the quality of life among the patients with diabetes, so that in the components associated with quality of life a significant difference was observed before and after the educational intervention in the test group $(p=0.017)$; however, there was no significant difference in the items in the control group (42). Diabetes self-care behaviors is required during life, and its acute and chronic complications can be prevented by constant pursuing, and its onset can be delayed (43). Health locus of control is the belief that health is controlled by internal or external fac- tors. The result of a study conducted by Ebadi Fard Azar et al. showed patients with higher score of self-care had higher score in inner locus of control as well. Also, they found that patients with higher score in self-care had lower score in chance locus of control (44).

Self-reporting was one of the limitations in this study, and it is recommended that other studies be conducted using interview methods.

\section{Conclusion}

Results revealed that education based on locus of control structure of attribution theory on self-care in patients with diabetes had a positive effect in disease control and that the mean scores of external and chance locus of control decreased and that of the internal locus of control increased. Therefore, self-care was improved in the patients. Hence, to improve the self-care behaviors and increase the health of patients with type II diabetes, improved educational interventions based on locus of control structure of attribution theory should be performed by diabetes associations and health centers. In these interventions, the improved internal locus of control and decreased external and chance locus of control are considered. Considering the importance of locus of control in participants and their beliefs about the effective factors, more studies should be conducted in this field.

\section{Acknowledgement}

This article was extracted from a Master's thesis approved by Vice Chancellor for Research and Technology, Iran University of Medical Sciences (No. 25593). The authors appreciate the officials of Babol Diabetes Association and the patients who participated in this study.

\section{Conflict of Interests}

The authors declare that they have no competing interests.

\section{References}

1. Zimmet P. The burden of type 2 diabetes: are we doing enough? Diabetes Metab. 2003;29(4 Pt 2):6S9-18.

2. Barth JH, Marshall SM, Watson ID. Consensus meeting on reporting glycated haemoglobin (HbAlc) and estimated average glucose (eAG) in the UK: report to the National Director for Diabetes, Department of Health. Diabet Med. 2008;25(4):381-2.

3. Al-Adsani AM, Moussa MA, Al-Jasem LI, Abdella NA, Al-Hamad NM. The level and Determinants of diabetes knowledge in Kuwaiti adult with type 2 diabetes. Diabetes Metab. 2009;35(2):121-128.

4. Shirinzadeh M, Shaker hosseini R, Hoshiyar rad A. [Nutritional value assessment and adequacy of dietary intake in type 2 diabetic patients]. Iranian J Endocrin \& Metab. 2009;11(1):25-32. (Persian)

5. Shaw JE, Sicree RA, Zimmet PZ. Global estimates of the prevalence of diabetes for 2010 and 2030. Diabetes Res Clin Pract. 2010;87(1):414.

6.Yazdanpanah B, Safari M, Angha P, Karami M, Emadi M, Yazdanpanah S, et al. Efficacy of Community-Based Participatory Research on Diabetes Care in Yasouj-Iran. Iran J Epidemiol. 2012;7(4): 1-8. (Persian)

7. Rakhshanderou S, Heidarnia AR, Rajab A. [The Effect of Health Education on Quality of Life in Diabetic Patients Referring to Iran Diabetes Association]. Daneshvar Med. 2006;13(5):15-20. (Persian)

8. Gagliardino JJ, Etchegoyen G. A model educational program for people with type 2 diabetes: a cooperative Latin American implementation study (PEDNID-LA). Diabetes Care. 2001;24(6):1001-7. 
9. Mahmoudi A. Effects of self-care planning on reduction of A1C hemoglobin in adults with diabetes mellitus. Med Sci J Islamic Azad Univ. 2006;16(3):171-6. (Persian)

10. Nadrian H, Morovati Sharifabad MA, Mirzaei A, Bahmanpur K, Moradzadeh R, Shariati AM. Relationship between quality of life, health status and self-care behaviors in patients with rheumatoid arthritis in Yazd. J Ilam Univ Med Sci. 2011;19 (2):15-25. (Persian)

11. Ghazanfari Z, Ghofranipor F, Rajab A, Ahmadi F. Effect of educational program based on James Brown on knowledge and attitude in patient with type II diabetes. Daneshvar. 2006;14(65):45-54. (Persian)

12. Chen SY, Wang HH. The relationship between physical function, knowledge of disease, social support and self-care behavior in patients with rheumatoid arthritis. J Nurs Res. 2007;15(3):183-92.

13. Clark M, Hampson SE, Avery L, Simpson R. Effects of a tailored lifestyle self-management intervention in patients with type 2 diabetes. Br J Health Psychol. 2004;9(Pt 3):365-79.

14. Glasgow RE, Hampson SE, Strycker LA, Ruggiero L. Personalmodel beliefs and social environmental barriers related to diabetes self-management. Diabetes Care. 1997;20(4):556-61.

15. Martinus R, Corban R, Wackerhage H, Atkins S, Singh J. Effect of psychological intervention on exercise adherence in type 2 diabetic subjects. Ann N Y Acad Sci. 2006;1084:350-60.

16. Rakhshanderou S, Heidarnia A, Rajab A. The effect of health education on life quality in diabetes patients. Daneshvar. 2006;13(63):15-20. (Persian)

17. Lin WC, Ball C. Factors affecting the decision of nursing students in Taiwan to be vaccinated against hepatitis B infection. J Adv Nurs. 2007;25(4):709-18.

18. Hawthrone K, Tomlin Son S. One to one teaching with picture- flash card health education for British Asians with diabetes England. Br J Gent Pvact. 2007;47(418):301-304.

19. Gary TL, Bone LR, Hill MN, Levine DM, McGuire M, Saudek C, et al. Randomized controlled trial of the effects of nurse case manager and community health worker interventions on risk factors for diabetes related complications in urban African Americans. Prev Med. 2003; 37(1):23-32.

20. Asner-Self, Kimberly; Schreiber, James B. A Factor Analytic Study of the Attributional Style Questionnaire with Central American Immigrants. Measurement and Evaluation in Counseling and Development 2004;37(3):144-153.

21. Weiner B. An attributional theory of achievement motivation and emotion. Psychol Rev. 1985;92(4):548-573.

22. Yazdanpanah A, Ghasemi A, Siamian H, Javadian M. The Study of the Attributional Style of the Students Studying in Mazandaran University of Medical Sciences in 2008-2009. J Mazandaran Univ Med Sci. 2011;21(82):84-88. (Persian)

23. Kuwahara A, Nishino Y, Ohkubo T, Tsuji I, Hisamichi S, Hosokawa T. Reliability and Validity of the Multidimensional Health Locus of Control Scale in Japan: Relationship with Demographic Factors and Health-Related Behavior. Tohoku J Exp Med. 2004;203(1):37-45.

24. Nikoogotar M. The role of attachment and health locus of control on diabetes self-care behaviors. Iran J Diabetes Lipid Disord. 2013; 12(4):309-316. (Persian)

25. Moshki M, Ghofranipour F, Azadfallah P, Hajizadeh E. Validity and Reliability of the Multidimensional Health Locus of Control (Form B) Scale in Iranian Medical Students. J Ofogh Danesh. 2006;12: 33-42.

26. Hatamloo Sadabadi M, Poursharifi H, Babapour Kheiroddin J. The role of health locus of control on self-care behaviors patients with type II diabetes. Med J Tabriz Univ Med Sci. 2011;33(4):17-22.

27. Chas Skinner T, Hampson SE. Personal Models of Diabetes in Relation to Self-Care, Well-Being, and Glycemic Control. Diabetes Care 2001;24(5):828-833.

28. Jalilian F, Zinat Motlagh, Solhi M. Effectiveness of Education Program on Increasing Self -Management among patients with Type II Diabetes. J Ilam Univ Med Sci. 2012;20(1):26-34. (Persian)

29. Agha Molaei T, Eftekhar H, Mohammad K. Application of health belief model to behavior change of diabetic patients. Payesh. 2005; 4(4):263-9. (Persian)

30. Viswanathan V, Shobhana R, Snehalatha C, Seena R, Ramachandran A. Need for education on foot care in diabetic patients in India. J Assoc Physicians India. 1999;47(11):1083-5.

31. Basa RP, McLeod B. Evaluation of a diabetes specialty centre: structure, process and outcome. Patient Educ Couns. 1995;25(1):23-9.

32. Hazavehei SMM, Sharifirad G, Mohebi S. The effect of educational program based on health belief model on diabetic foot care. Int J Dia- betes Dev Ctries. 2007;27(1):18-23.

33. Giral Guembe A, Magana Moreno A, Arriazu Enrique C, Elviro Bodoy T, Aguado Magana G, Sandua Sada M. [Diet based on rations. Practical teaching for type II diabetics]. Rev Enferm. 1998; 21(236):11-4.

34. Rickheim PL, Weaver TW, Flader JL, M Kendall DM. Assessment of Group versus Individual Diabetes Education: A randomized study. Diabetes Care. 2002;25(2):269-74.

35. Jacobson AM, de Groot M, Samson JA. The evaluation of two measures of quality of life in patients with type I and type II diabetes. Diabetes Care. 1994;17(4):267-74.

36. Brannon L, Feist J. Health Psychology: An Introduction to Behavior and Health. 11th edition. USA: Cengage Learning; 2013.

37. Najmi B, Ahadi H, Delavar A, Hashemipor M. The effectiveness of multidimensional psychological treatment in enhancing the adherence to medical treatment in adolescents with type 1 diabetes. Behav Sci Res. 2007;5(2):127-37. (Persian).

38. Clark M, Hampson SE, Avery L, Simpson R. Effects of a tailored lifestyle self-management intervention in patients with type 2 diabetes. Br J Health Psychol. 2004;9(3):365-79.

39. Glasgow RE, Hampson SE, Strycker LA, Ruggiero L. Personalmodel beliefs and social environmental barriers related to diabetes self-management. Diabetes Care. 1997;20(4):556-61.

40. Taghdisi MH, Borhani M, Solhi M, Afkari ME, Hosseini ME. Effect of educational program based on PRECED model on quality of life in patients with type II diabetes. J Ofogh Danesh. 2010;13(1):29-36. (Persian)

41. Moeini B, Jalilian M, Hazavehei SMM, Moghim Beigi A. Promoting Physical Activity in Type 2 Diabetic Patients: A Theory-Based Intervention. ISC E-journals 2012;8(5):824-833. (Persian)

42. Baghianimoghadam MH, Afkhami Ardekani M. The effect of educational intervention on quality of life of diabetic patients type 2, referee to diabetic research centre of Yazd. Ofoghe Danesh. 2007;3(4):21-30. (Persian)

43. Parham M, Rasooli A, Safaeipour R, Mohebi S. Assessment of effects of self-caring on diabetic patients in Qom diabetes association 2013. Quart J Sabzevar Univ Med Sci. 2014;21(3):473-484.

44. Ebadi Fard Azar F, Heidari H, Solhi M. Relationship between selfcare behavior and health locus of control in patients with type II diabetes. Razi J Med Sci. 2016;23(146):84-92. (Persian) 